\title{
Production and physicochemical characteristics of strawberry cultivars produced in organic cropping system
}

\section{Características produtivas e físico-químicas de cultivares de morangueiro produzido em sistema de cultivo orgânico}

\section{José Tobias Marks MACHADOㄹ; Jeferson TONIN'; Jorge Atilio BENATI²; Lisiane SOBUCKI²; Evandro Pedro SCHNEIDER ${ }^{3}$; Débora Leitzke BETEMPS ${ }^{4}$}

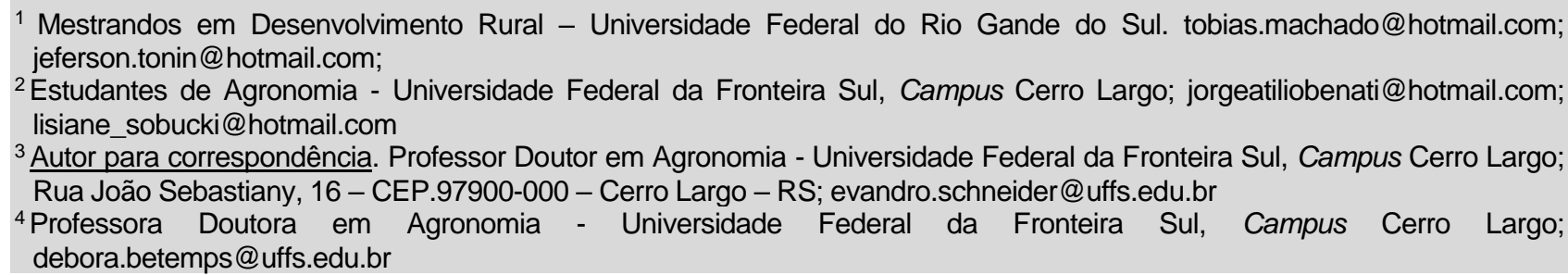

Recebido em: 06-05-2015; Aceito em: 23-03-2016

\begin{abstract}
The conventional production of strawberries has been characterized by high use of inputs resulting in chemical waste in the fruit. Strawberry produced on organic cropping system becomes important, because have more economic autonomy to family farms and reaches levels ecological, social and economic sustainability. The production and physicochemical characteristics of four short-day strawberry plants - Campinas, Chandler Dover and Vila Nova - were evaluated in order to obtain information to the development of organic system productive in the northwestern region of Rio Grande do Sul state, in Brazil. The experiment was conducted between May $1^{\text {st }}$ and November $3^{\text {rd }}, 2014$. As regarded production characteristics, in each productive month and in total accumulated of the cycle were evaluated the mass and the quantity of accessory fruit produced by the plant. The physicochemical characteristics were determined through the soluble solid content, titratable acidity, $\mathrm{pH}$ and the color of the accessory fruits. Referring to the productivity, 'Campinas' stood on the other cultivars, showing bigger mass and total accessory fruit number. About the relation of soluble solid content and titratable acidity, the cultivars Chandler and Dover reached the best results, whereas the color of the 'Chandler', 'Campinas' and 'Villa Nova' accessory fruits submitted higher ${ }^{\circ H u e}$ value.
\end{abstract}

Additional keywords: ecologic base; Fragaria x ananassa; quality; short-day cultivars.

\begin{abstract}
Resumo
A produção convencional de morangueiro tem-se caracterizado pela utilização de carga abusiva de insumos químicos, acarretando sérios problemas de resíduos destas substâncias no produto final. Enfatiza-se, assim, a relevância da produção do morangueiro em sistema orgânico, a qual geralmente tem maior potencial de apropriação pela produção familiar, dada sua maior independência do ponto de vista econômico e a potencialização para níveis crescentes de sustentabilidade ecológica, social e econômica. Objetivou-se, neste trabalho, avaliar características produtivas e físico-químicas de quatro cultivares de morangueiro de dia curto, produzido em sistema de cultivo orgânico, nas condições do noroeste do Estado do Rio Grande do Sul. As cultivares 'Campinas', 'Chandler', 'Dover' e 'Vila Nova' foram testadas, no período de 01-05 a 03-11-2014. Foram avaliados a massa e o número de frutos produzidos por planta, em cada mês de produção e no acumulado total do ciclo. Para as características físico-químicas, foram avaliados o teor de sólidos solúveis (SS), a acidez titulável (AT), o pH e a coloração dos frutos. Para 'Campinas', obteve-se maior massa e número total de frutos produzidos por planta. Quanto à relação SS/AT, as cultivares Chandler e Dover apresentaram os maiores índices em relação às demais. Para a coloração dos frutos, 'Dover' apresentou coloração mais próxima ao vermelho intenso em seus frutos.
\end{abstract}

Palavras-chave adicionais: base ecológica; cultivares de dias curtos; Fragaria $x$ ananassa; qualidade.

\section{Introduction}

Strawberry (Fragaria $X$ ananassa) is a quite susceptible plant to attack by pests and diseases, and the conventional fruit production uses abusive load of chemical inputs, resulting in serious waste problems of these substances in the final product (Darolt, 2008). According to data from the Pesticide Residue Analysis Program, ANVISA (2013), 59\% of samples showed unsatisfactory results, highlighting 
the importance of the development of production systems that reduce or eliminate pesticides use.

Strawberry chain has great social and economic importance (Brackmann et al., 2001), due to have high added value (Henz, 2010) and mobilize producers with varied production scales which cover local and global markets. In this aspect, it is even emphasized the importance of strawberries production in organic system, and according to Moreira (2003), they are generally more appropriable by family production, due to its greater independence from the economic point of view and potentiation for increasing levels of ecological, social and economic sustainability.

The choice of cultivar to be used is a great importance to the success of strawberry ploughing, and this aspect becomes even more important when organic cropping systems are adopted (Strassburger et al., 2012). Camargo (2008) and Avila et al. (2012) found significant differences in aspects related to productivity and chemical characteristics of organic strawberry when compared to conventional. Chitarra \& Chitarra (2005) assert that quality differs between cultivars of same species according to the origin and production conditions. The productive adaptability characteristics of strawberry require further studies on cultivars behavior in organic cropping system, carried out in the region where intend to develop the production.

The production of the state of Rio Grande do Sul is concentrated essentially in three regions: Vale do Caí, Serra Gaúcha and South region (Specht \& Blume, 2011), however, strawberry production has expanded its production frontier to other regions of the state of Rio Grande do Sul. The northwest region of the state has a higher degree accumulation during the day, with low nighttime temperatures and high at daytime, different from the condition found in commonly strawberry producing regions, highlighting the need for regionalized experiments to better understand the development dynamics of strawberry cultivation, as recommended by several authors (Cansian et al., 2002; Carvalho et al., 2013) in saying that local effect has an influence on the response of different cultivars.

Hence, this study aimed to evaluate production and physicochemical characteristics of four shortday strawberry cultivars produced in organic cropping system, at the conditions of the North-western state of Rio Grande do Sul.

\section{Material and methods}

The experiment was conducted in Cerro Largo - RS, with approximate location of latitude $28^{\circ} 08^{\prime}$ South, longitude $54^{\circ} 44^{\prime}$ West and $230 \mathrm{~m}$ altitude above sea level. The site soil was classified as Neosols and Cfa climate according to Köppen.

For the experiment, were used three beds arranged in East-west direction with dimensions of $7.2 \mathrm{mx} 1.2 \mathrm{~m}$ (length $\mathrm{x}$ width), sheltered by short tunnel, with two drip tapes for each bed as irrigation system. It was used double-sided polyethylene of white and black color $(250 \mu \mathrm{m})$ as ground cover. Acidity and soil fertility correction was performed with limestone shells use, stabilized pig and bovine manures which were incorporated into soil in consistent amounts with prior chemical analysis (Table 1), before seedlings transplant occurred in 05-01-2014.

Table 1 - Soil chemical analysis of the experimental deployment area.

\begin{tabular}{|c|c|c|c|c|c|}
\hline $\mathrm{pH}\left(\mathrm{H}_{2} \mathrm{O}\right)$ & $\mathrm{Al}^{3+}$ & $\begin{array}{l}\mathrm{Ca}^{2+} \\
---(\mathrm{cm}\end{array}$ & $\mathrm{Mg}^{2+}$ & $\mathrm{H}^{+}+\mathrm{Al}^{3+}$ & Texture Class \\
\hline 5.40 & 0 & 35.67 & 8.11 & 2.80 & 3 \\
\hline $\mathrm{Al}^{3+}$ Saturation & Base saturation & M.O. & Clay & $\begin{array}{c}\text { CTC } \\
\left(\mathrm{cmol}_{\mathrm{c}} \mathrm{dm}^{-3}\right)\end{array}$ & $\begin{array}{l}\mathrm{CTC} \mathrm{pH} \\
\left(\mathrm{cmol}_{\mathrm{c}} \mathrm{dm}^{-3}\right)\end{array}$ \\
\hline 0 & 94 & 2.70 & 25 & 44.70 & 47.50 \\
\hline$P$ & $\mathrm{~K}$ & $\begin{array}{l}n \\
---(n\end{array}$ & $\mathrm{Cu}$ & $S$ & B \\
\hline 18.90 & 340 & 6.98 & 10.36 & 9.3 & 0.2 \\
\hline
\end{tabular}

Fifteen days after transplant carried out the application of Trichoderma spp., in soil by fertirrigation, in order to induce antagonism to gray mold (Botritys cinérea) and anthracnose (Colletotrichum spp.). After seedling transplant, fertirrigation was fortnightly realized with Supermagro biofertilizer $1 \%$ concentration and used dose of $250 \mathrm{~L} \mathrm{ha}^{-1}$. For pests and diseases control was used Bordeaux mixture (1\%), Neem exctract (Azadirachta indica) $1 \%$ and Curamor (Bordeaux mixture and plant extracts product), using for all 1,300 liters mixture per hectare. The use of such products is ensured by the
Normative Instruction 17, of the Ministry of Livestock and Supply Agriculture (BRASIL, 2007), for organic cropping systems. The frequency application of these products varied according to the need observed during the cropping cycle. Sick leaves and fruits were removed weekly as a measure to reduce disease inoculum.

The tested cultivars were Campinas, Chandler, Dover and Vila Nova, characterized as short-photoperiod cultivars, and had positive responses in the four treatments, installed under experimental design of randomized blocks, with three 
blocks. Each experimental plot consisted of 18 plants, arranged in three rows with $0.3 \mathrm{~m}$ spacing between rows and plants, corresponding to 11.11 plants $/ \mathrm{m}^{2}$. From 18 plants in each experimental unit, three plants located on each one of two sides of the same, were considered borders, thus 12 plants were evaluated in each experimental unit, hence twelve sampling units in each experimental unit.

Accumulated productivity (total) and monthly distribution during the cycle, expressed in grams per plant, number of fruits per plant and mean weight were evaluated. The mass, both total and monthly, were determined by dividing weight by the number of harvested fruits. Only commercial fruit which did not have deformations due to pests and / or diseases were evaluated. Harvests began on 09-01-2014 and lasted until 12-03-2014, totaling 28.

For quality parameters, evaluated physicochemical variables were: soluble solids content (SS), titratable acidity (TA), relation between soluble solids and titratable acidity (SS / TA), $\mathrm{pH}$, and fruit color. During the cycle seven samples were collected and analyzed, performed on 09-11; 09-25; 10-09; 10-23; 11-07; 11-20; and 11-03 these being made in laboratory. Soluble solids content was determined using bench digital refractometer Instrutherm RTD-95. We used the fruit pure juice, and expressed readings in ${ }^{\circ}$ Brix. The titratable acidity was determined by titrating $10 \mathrm{~mL}$ of juice and $100 \mathrm{~mL}$ of distilled water to $\mathrm{pH} 8.1$ using $0.1 \mathrm{~N} \mathrm{NaOH}$ solution, the result was expressed as citric acid percentage. The $\mathrm{pH}$ reading was performed with bench digital $\mathrm{pH}$ meter MS TECNOPOM mPA-210, as described by Medeiros et al. (2009). Epidermis color was determined using a Minolta CR 400/410 colorimeter with $8 \mathrm{~mm}$ reading diameter and D-65 light source by the color threedimensional space reading $L^{*} a^{*} b^{*}$ also known as the CIE Lab system.

Significant variables by $F$ test $(P \leq 0.05)$ had means compared to Tukey test at $5 \%$ error probability, though Assistat statistical program.

\section{Results and discussions}

Yield showed no significant difference in the first month evaluation (September). In the second evaluation (October), 'Campinas' showed higher production than 'Chandler' and 'Dover', not differing from 'Vila Nova'. In the third evaluation (November), 'Campinas' remained as the more productive cultivar differentiating from 'Vila Nova' and 'Chandler', not differing from 'Dover'. In total accumulated 'Campinas' it was superior to 'Chandler' and 'Dover', not differing from 'Vila Nova' (Figure 1).

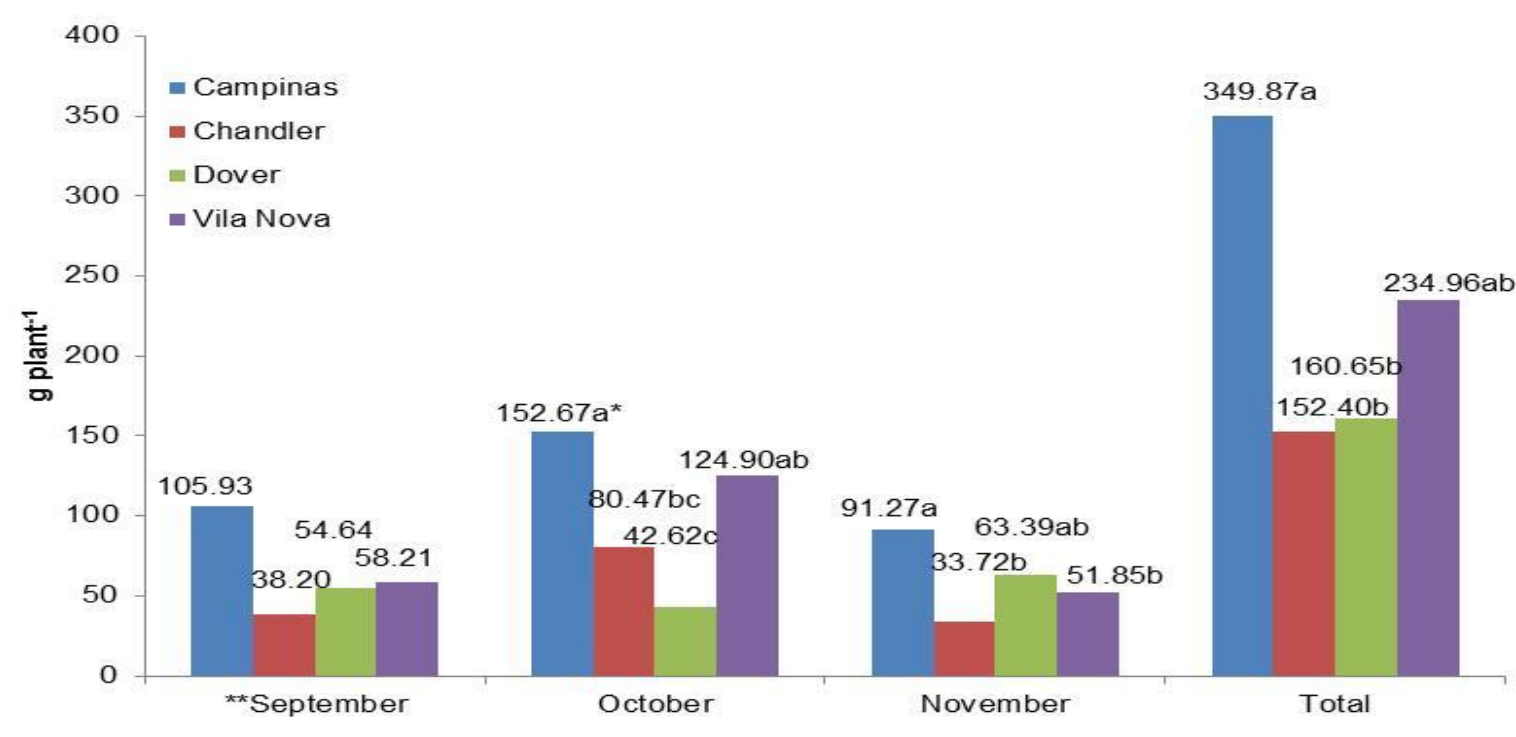

* treatments with means followed by same letter, do not differ each other by Tukey test at $5 \%$ error probability.

** There was no statistical significance. $C V=21.2 \%$.

Figure 1 - Monthly distribution and total accumulated of productivity (g plant $\left.{ }^{-1}\right)$.

Schuch \& Barros (2010), whereas evaluating eight strawberry cultivars in conventional production system, in the Depression Central Region of Rio Grande do Sul, found no statistical difference in productivity between the four cultivars evaluated in this study. The yield of cultivar Campinas with $349.87 \mathrm{~g}$ plant $^{-1}$ obtained in this study, exceeded $300.8 \mathrm{~g} \mathrm{plant}^{-1}$ indicated by the authors, however, in the case of cultivar Vila Nova, the $234.96 \mathrm{~g} \mathrm{plant}^{-1}$ obtained in study, were lower than $367.2 \mathrm{~g}$ plant ${ }^{-1}$ produced in Central Depression of Rio Grande do Sul and may be indicative of different adaptability to the production system and / or cropping region.

Castro et al. (2003) conducting experiment in organic production system in Viçosa - MG, and using 
cultivars Campinas and Dover, showed similar yields to those obtained in this work for cultivar Campinas, in agreement with the results obtained in this work. However, at this same work 'Campinas' does not differentiate from 'Dover', differing from that found in this experiment, in which this cultivar was inferior to 'Campinas'. In an experiment conducted in Paraná, also in an organic system, Silva (2011) indicates differences between 'Dover' and 'Campinas' productions, the first statistically superior to the second, confirming the need for cultivars behavioral assessment in different regions of cultivation.

Regarding to fruit numbers (Figure 2), in every month and total accumulated productive cycle were significant differences between treatments. To the mass, differences were significant on September and total accumulated (Figure 3).

In the first evaluation for fruit number, cultivars did not differentiate among themselves, to the mass, 'Vila Nova' differentiated from 'Campinas' and 'Chandler', producing fruit with higher weight, but not differing from Dover. In the second and third evaluation, Campinas differentiated from the other three cultivars with increased production of fruit number. In accumulated, Campinas showed a larger amount of produced fruits. For the mass, 'Vila Nova' exceeded 'Campinas', not differing from Dover and Chandler. Fruit weight is directly related to its size, which is an influence factor on the choice of cultivars in commercial exploration of strawberry.

Testing 'Dover', 'Campinas' and other four cultivars in Atibaia and Piracicaba, SP, Conti et al. (2002) detached 'Campinas' as the cultivar with more number of fruit in the cycle, not differing from 'Dover'. In the same study, Dover differentiated from Campinas producing fruit with higher weight. The authors also reported considerable differences between the fruit weight of the same cultivar in both cities, indicating different behavior of genotypes

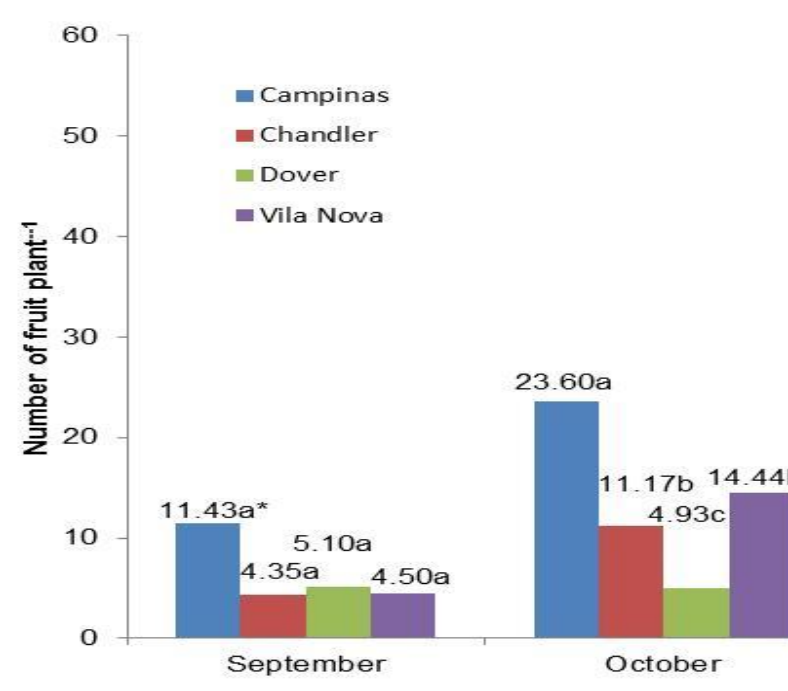

between two production regions, since condition management were the same in both experiments.

Calvete et al. (2008), on experiment in conventional system in Passo Fundo, RS, has data in which 'Dover' presents as a cultivar with larger production on number of fruits, statically differentiating from 'Campinas', which does not differ from cultivars with lower production, in disagreement with this work found.

The weight found in this work to 'Vila Nova' fruits of $9.21 \mathrm{~g}$, is superior to the verified by Schuch \& Barros (2010), in central region of Rio Grande do Sul, for the same cultivar. For the same authors and in agreement with the findings, 'Vila Nova' stands on 'Campinas' with fruits with higher weight, does not also differentiating from Dover. In many experiments, similar to this work, 'Campinas' tends to differentiate as fruit holder cultivar with lower weight, or at last, does not differ from smaller ones (Conti et al., 2002; Silva, 2011; Castro et al., 2003; Schuch \& Barros, 2010).

Analyzing all three production-related factors (productivity, mass and number of fruits), 'Campinas' is the cultivar with increased production, mass and number of fruits, however with mean fruit weight, is significantly inferior to the others. 'Vila Nova', in turn, total productivity does not differ from 'Campinas', with smaller fruits numbers. Owing to this characteristic, 'Vila Nova' has presented the highest mean fruit weight. Cultivars with large number of fruit and lower mean weight, as cultivar Campinas, are preferred for processing, while cultivars with higher weight, such as 'Vila Nova' are intended for fresh consumption.

For quality parameters, coloration shows significant differences between the four cultivars (Table 2).

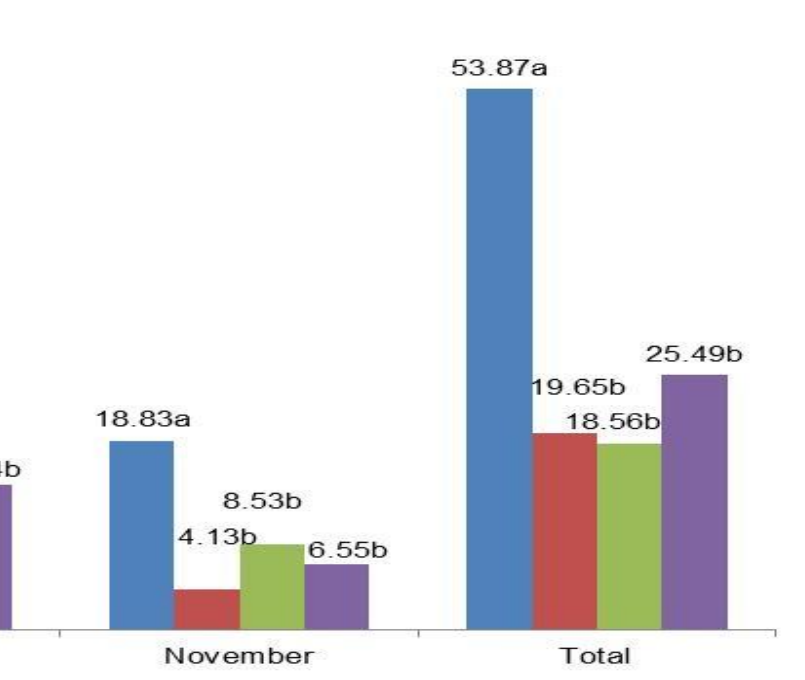

* treatments with means followed by same letter, do not differ each other by Tukey test at $5 \%$ error probability. CV $=20.4 \%$.

Figure 2 - Monthly distribution and total accumulated of fruitplant ${ }^{-1}$. 


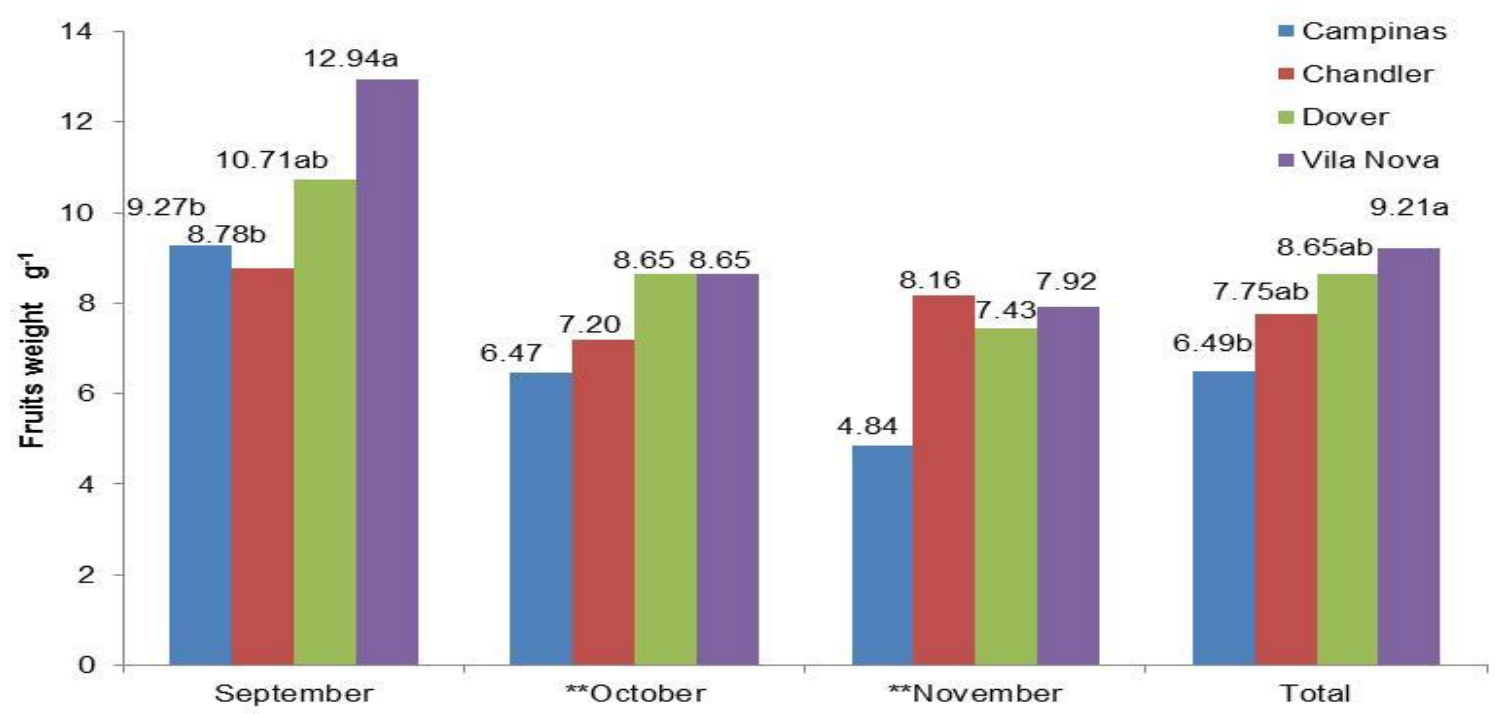

* treatments with means followed by same letter, do not differ each other by Tukey test at $5 \%$ error probability.

** There was no statistical significance. CV $=12.0 \%$.

Figure 3 - Monthly distribution of average size fruit and average size on total cycle.

Table 2 - Solubs solids (SS), titratable acidity (TA), ratio SS/TA, coloration and $\mathrm{pH}$ of cultivars Chandler, Campinas, Dover and Villa Nova.

\begin{tabular}{llllll}
\hline Cultivar & SS & TA & "ratio" & ${ }^{\circ H u e}$ & $\mathrm{pH}$ \\
\hline Campinas & $6.44 \mathrm{a}^{*}$ & $1.54 \mathrm{a}$ & $4.35 \mathrm{~b}$ & $29.35^{\mathrm{a}}$ & $3.27^{* *}$ \\
Chandler & $6.18 \mathrm{a}$ & $1.06 \mathrm{~b}$ & $6.15 \mathrm{a}$ & $30.01^{\mathrm{a}}$ & 3.45 \\
Dover & $5.13 \mathrm{~b}$ & $1.04 \mathrm{~b}$ & $4.94 \mathrm{ab}$ & $25.19 \mathrm{~b}$ & 3.32 \\
Vila Nova & $5.69 \mathrm{ab}$ & $1.41 \mathrm{a}$ & $4.04 \mathrm{~b}$ & $26.96 \mathrm{ab}$ & 3.30 \\
\hline CV $(\%)$ & 8.73 & 17.93 & 18.42 & 8.68 & 5.28
\end{tabular}

${ }^{*}$ Treatments with means do not followed by same letter vertically differ each other by Tukey test at $5 \%$ of error probability.

** There was no statistical significance.

Cultivars Chandler, Campinas and Villa Nova had superior values of Hue angle. 'Dover' had inferior results to 'Chandler' and 'Campinas'. Hue angle indicates the value in degree corresponding threedimensional diagram of colors, as $0^{\circ}$ - red, $90^{\circ}$ - yellow, $180^{\circ}$ - green and $270^{\circ}$ - blue (Silva et al., 2011). Thus, lower values of Hue angle indicate coloration nearest to deep red, where 'Dover' detaches among cultivars for presenting fruits with more intense color. Deep red color is a preferred feature by the consumer, although usually do not change the nutritional value of these (Chitarra \& Chitarra, 2005).

Cultivars Campinas and Chandler had higher soluble solid contents compared to 'Dover', do not differing from 'Villa Nova' (Table 1). Conti et al. (2002) in similar work in Atibaia and Piracicaba, in State of São Paulo, also observed that soluble solids concentration in 'Campinas' was higher than 'Dover'. Borsatti et al.(2009), in a study on testing cultivars performed in Paraná, also found low values for soluble solids concentration to cultivar Dover (5.57). Soluble solids content is important to meet the costumer market demand that prefer sweet fruits. Soluble solids are a climate-dependent parameter (Chitarra \& Chitarra, 2005), i.e., differentiated condi- tions of the region in question may have significantly influenced on soluble solid contents.

Regarding titratable acidity, 'Campinas' and 'Villa Nova' obtained the highest values. The relation between soluble solids and titratable acidity values ("ratio") is one of the most significant variables in evaluating fruit flavor, where cultivar Chandler detached, compared to Campinas and Villa Nova, does not differing from Dover.

Cultivar Chandler has, as described above, high soluble solids content and low acidity index, providing the highest values of "ratio" found. The values for soluble solids in cultivar Dover were low; however, its low acidity content allowed the good performance in of "ratio" evaluation. 'Villa Nova' and 'Campinas' obtained similar results of soluble solids and high acidity, providing low "ratio" values.

The titratable acidity values found in this study (Table 1) can be considered superior, although lower soluble solids values are commonly found in the literature. The harvest point used $(75 \%$ of red color) can interfere considerably in the present fruit acids content, and according to Brody (1996), during the maturation process organic acid content tends to decrease due to oxidation in citric acid cycle as a result of breathing. 
For $\mathrm{pH}$ assessments, data were not significant ranging from 3.27 ('Campinas') to 3.45 ('Chandler'), as shown in Table 1.

\section{Conclusions}

Considering set of information, for the conditions of North-western of the State of Rio Grande do Sul and in organic cropping system of production, cultivars 'Campinas' and 'Vila Nova' proved to be the most productive. 'Campinas' showed the largest number of produced fruits, however fruit with lower weight. 'Vila Nova presented fruits with higher weight, but lower quantity of fruit. Cultivars Chandler and Dover had higher soluble solids / titratable acidity relation ("ratio"), and Dover showed lower soluble solid contents and greater characteristic of deep red colour in its fruits.

\section{References}

ANVISA (2013) Programa de análise de resíduos de agrotóxicos em alimentos (Para): Relatório de atividades de 2011 e 2012. Brasília, outubro 2013. $44 \mathrm{p}$. Disponível

em:

<http://portal.anvisa.gov.br/wps/wcm/connect/58a558 0041a4f6669e579ede61db78cc/Relat\%C3\%B3rio+P ARA+2011-12+-+30_10_13_1.pdf?MOD=AJPERES> (Acesso em: 5 abr. 2015).

Avila JMC, Toralles RP, Cantillano FF, Peralba, PCR, Pizzolato TM (2012) Influência do sistema de produção e do armazenamento refrigerado nas características físico-químicas e no desenvolvimento de compostos voláteis em morangos. Ciência Rural 42(12):103-115. doi: 10.1590/S010384782012005000115.

Borsatti FC, Godoy WI, Farinácio D, Fanguetto, RF, Simonetti D (2009) Avaliações químicas de dez cultivares de morangueiro produzidos em sistema orgânico na região sudoeste do Paraná.Revista Brasileira de Agroecologia 4(2):31-34.

Brackmann A, Hunsche M, Waclawovski A, Donazzolo J (2001) Armazenamento de morangos cv. Oso Grande (Fragaria x ananassa L.) sob elevadas pressões parciais de $\mathrm{CO}_{2}$. Current Agricultural Science and Technology 7(1):10-14.

BRASIL (2007) Decreto oㅜ 6.323, de 27 de dezembro de 2007. Regulamenta a Lei no 10.831 , de 23 de dezembro de 2003, que dispõe sobre a agricultura orgânica, e dá outras providências. Diário Oficial \{da\} República Federativa do Brasil. Brasília, 27 de dezembro de 2007. Disponível em: <http://www.agricultura.gov.br/arq_editor/file/Desenvo Ivimento_Sustentavel/Organicos/Legislacao/Nacional/ Decreto_n_06_323_de_27-12-2007.pdf> (Acesso em 20 jan. 2015).
Brody AL (1996) Envasado de alimentos en atmosferas controladas, modificadas y vacio. Acribia, 220p.

Calvete EO, Mariani F, Wesp CL, Nienow AA, Castilhos T, Cecchetti D (2008) Fenologia, produção e teor de antocianinas de cultivares de morangueiro em ambiente protegido. Revista Brasileira de Fruticultura 30(2):396-401. doi: 10.1590/S010029452008000200022.

Camargo IKP (2008) Produtividade e qualidade de cultivares de morangueiro em sistemas orgânico e convencional na região de Guarapuava-PR. Unicentro (Dissertação de mestrado em Produção Vegetal). 86p.

Cansian RL, Moss AJ, Leontiev-Orlov O, Barbieri C, Murtelle G, Pauletti G, Rota L (2002) Comportamento de cultivares de morango (Fragaria $x$ ananassa) na região do Alto Uruguai do Rio Grande do Sul. Current Agricultural Science and Technology 8(2):103-105.

Carvalho SF, Ferreira LV, Picolotto L, Atunes LEC, Cantillano RFF, Amaral PA, Weber D, Malgarim MB (2013) Comportamento e qualidade de cultivares de morango (fragaria $x$ ananassa duch.) na região de Pelotas- RS. Revista Iberoamericana de Tecnologia Postcosecha 14:176-180.

Castro RL, Casali VWD, Barella TP, Santos RHS, Cruz CD (2003) Produtividade de cultivares de morangueiro em sistema de cultivo orgânico. Horticultura Brasileira 21(2):227-230. doi: $10.1590 /$ S0102-0536200300020002.

Conti JH, Minami K, Tavares FCA (2002) Produção e qualidade de frutos de diferentes cultivares de morangueiro em ensaios conduzidos em Atibaia e Piracicaba. Horticultura Brasileira 20(1):10-17. doi: 10.1590/S0102-05362002000100002.

Chitarra MIF, Chitarra AB (2005) Pós-Colheita de frutas e Hortaliças: Fisiologia e Manuseio, $2^{\underline{a}}$ UFLA. $785 \mathrm{p}$.

Darolt MR (2008) Morango orgânico: opção sustentável para o setor. Revista Campo \& Negócios2(34):58-61.

Henz GP (2010) Desafios enfrentados por agricultores familiares na produção de morango no Distrito Federal.Horticultura Brasileira 28(3):260-265. doi: 10.1590/S0102-05362010000300003

Medeiros SAF, Yamanishi OK, Peixoto JR, Pires MC, Junqueira MTV, JGBL Ribeiro (2009) Caracterização físico-química de progênies de Maracujá-roxo e Maracujá-azedo cultivados no Distrito Federal. Revista Brasileira de Fruticultura 31(2):492-499. doi: 10.1590/S0100-29452009000200025. 
Moreira RM (2003) Transição agroecológica: conceitos, bases sociais e a localidade de Botucatu/SP. Unicamp (Dissertação de mestrado em Engenharia Agrícola) 139p.

Schuch, SML, Barros IBI (2010) Caracterização agronômica de cultivares de morangueiro na região da Depressão Central no RS. Pesquisa Agropecuária Gaúcha16(1-2):59-65.

Silva MC, Atarassi ME, Ferreira MD, Mosca, MA (2011) Qualidade pós-colheita de caqui 'Fuyu' com utilização de diferentes concentrações de cobertura comestível. Ciência Agrotecnica 35(1): 144-151.
Silva TP (2011) Características produtivas e físicoquímicas de frutos de morangueiro orgânico cultivado com o uso de extrato de algas. UFPR (Dissertação de mestrado em Ciências). 121p.

Specht S, Blume R (2011) A competividade da cadeia do morangueiro no Rio Grande do Sul. Revista Administração e Negócio da Amazônia 3(1):35 59 .

Strassburger AS, Peil RMN, Schwengber JE (2012) Dinâmica de crescimento da cultura do morangueiro em sistema orgânico. Pesquisa Agropecuária Gaúcha 18(1):45-52. 